\title{
Hogyan befolyásolja a vendégek személyisége a magyar wellness-szállodákkal kapcsolatos elégedettséget?
}

\author{
Szerzők: Kökény László ${ }^{1}$ - Kenesei Zsófia²
}

Kutatási tanulmányok szerint egyre nagyobb teret kap a vállalatok marketingtevékenységében az a felfogás, hogy a fogyasztók egyediek, saját, személyiségükből következô értékrenddel bírnak. Erre a felfogásra a vállalatok is egyre inkább nyitottak, mivel a céljuk a minél hatékonyabb kiszolgálás és ezáltal a minél nagyobb profit. A személyiségtípusok azonositásával lehetôség nyílik a fogyasztók személyiségalapú csoportosítására. Kutatásunk célja azt megvizsgálni, hogy a fogyasztói személyiségtípusok hogyan, és milyen mértékben befolyásolják a szállodai szolgáltatással kapcsolatos elégedettséget. Az elégedettség területét a szállodai szolgáltatás tényezôire fókuszáljuk, és a szakirodalom alapján különbözó részterületeket alakítunk ki, mint például a fizikai környezettel és a személyzettel kapcsolatos elégedettség. A személyiségtípus elemzéshez a Big Five Faktor tesztet használjuk. Összességében megállapitható, hogy a személyiségtípusok közül a barátságosság és a tudatosság szignifikánsan befolyásolja, a vártnak megfeleló irányba, a személyzetre és a fizikai környezetre vonatkozó elégedettség faktort. Ezzel ellentétben a neuroticitás, az extraverzió és a nyitottság egyáltalán nem befolyásolja szignifikánsan egyik elégedettség faktort sem.

Kulcsszavak: szállodai elégedettség, személyiségtípus, Big Five Faktor teszt, korrelációelemzés.

\section{Bevezetés}

Kutatásunk során a magyar fogyasztókat a hazai wellness-szállodák piacán vizsgáljuk. Azért esett választásunk erre a területre, mert a gazdasági világválság előtt számos wellness-szállodai beruházás indult. Ezen beruházások többsége nélkülözött mindenféle piaci szempontot, ugyanis fogyasztói oldalról nem volt olyan nagymértékú igény ezen a területen, mint azt a beruházók gondolták. A készülő beruházások helyzetét tovább rontotta a gazdasági világválság egyik negatív hatása, a drasztikus keresletcsökkenés egy túlkínálati piacon. Ezen vállalatok kénytelenek voltak költségszint alatti árazást alkalmazni, és csak néhány esetet leszámítva foglalkoztak azzal, hogy a fogyasztókat árcsökkentés nélkül, jól pozícionált, hatékony, egyénre szabott szolgáltatást nyújtva érjék el. Ha jól ismerik a fogyasztóikat és az elégedettségüket meghatározó tényezőket, valószínúleg nem alakult volna ki ez a negatív irányú árspirál. Kutatásunkkal hozzá szeretnék járulni ahhoz, hogy a szállodák felkészültebbek legyenek egy esetleges jövőbeni kereslet-

\footnotetext{
PhD-hallgató, Budapesti Corvinus Egyetem, laszlo.kokeny2@uni-corvinus.hu

2 egyetemi tanár, Budapesti Corvinus Egyetem,

zsofia.kenesei@uni-corvinus.hu
}

csökkenést előidéző válság esetén oly módon, hogy ismerik az elvárások mögött meghúzódó személyiségtípusokat és értékeket, ami által növelhetik a szolgáltatás színvonalát, amelyet a fogyasztók igényei alapján alakítanak ki. Mindez hatással van az elégedettségre, ami hosszú távon lojalitáshoz is vezethet, és a szállodák profitrátáját növelheti.

Kutatásunk kvantitatív elemzést tartalmaz, amelyben a válaszolók egy kétrészes kérdőívet töltöttek ki. A kérdőív első felében a 25 kérdésből álló, személyiségre jellemző, egyszerú, rövid állításokra kellett válaszolniuk, oly módon, hogy az adott állítás mennyire jellemzô rájuk az egytől ötig terjedő Likert-skálán. A személyiségtesztet a legelismertebb Big Five Faktor elmélet mentén alakítottuk ki. A kérdőív második felében a szállodai szolgáltatás tényezőivel kapcsolatos, általános elégedettségük mértékét kellett megadniuk a kitöltóknek, szintén egy egytől ötig terjedő skálán. A személyiségjegyeket faktorokba csoportosítottuk, majd elemeztük a létrehozott faktorok hatását a szolgáltatás tényezőivel kapcsolatos elégedettségre vonatkozóan.

\section{Szakirodalmi áttekintés és módszertan}

A szolgáltatásoknál, elégedettség szempontjából, a szakirodalmak legtöbbször az észlelési oldalt és az ott megjelenő tényezók közötti hatásokat vizsgálják. Négy fó dimenzió jelenik meg ezekben a ha- 
Lektorált tanulmányok

tásmodellekben, ami általában az arculat tényezőjével kezdődik, vagy abból indul ki, majd a három fó észlelés következik: az észlelt ár, az észlelt minőség és az észlelt érték (MILFELNER-KORDA 2011, OH 1999). Más kutatások a dolgozói elégedettséget is vizsgálják, valamint ezek hatását a fogyasztói elégedettségre (SPINELLI-CANAVOS 2000). Nagy szakirodalma van a szolgáltatói környezet hatás-kutatásának is (BITNER 1992, BAKER 1987). A szakirodalom szerint a percepciókat erősen befolyásolják az elózetes elvárások és a szerzett tapasztalatok. Az elvárások oldalának számos modelljét állították fel ZEITHAML és szerzőtársai (1993), viszont a személyhez köthetô, értékekhez kapcsolódó területeket csak az utóbbi néhány évben kezdték el vizsgálni (EKINCI et al. 2008; JANI-HAN 2013 és 2014). Vannak megközelítések, amelyek szerint a reklámzajban nemcsak a fogyasztók általános igényeire kell koncentrálni, hanem az érzelmeikre, az értékeikre és a személyiségükre is (JANI-HAN 2013). Ha ezek a tényezők pontosan kerülnek definiálásra - amely meglehetősen nagy kihívás a kutatók számára -, akkor megérthetóek az elvárások alapjai, amelyból aztán könnyebben határozhatóak meg az észlelést jellemző okok, amelyek az elégedettséghez járulnak hozzá (BAUER et al. 2009, KENESEI-KOLOS 2014).

\subsection{AZ ELÉGEDETTSÉG MÉRÉSE A SZÁLLODÁKBAN ÉS A VENDÉGLÁTÁSBAN}

OH (1999) kutatása rámutat arra, hogy mennyire fontos az elégedettség mérése. Azt vizsgálta, hogy az elégedettség miképpen biztosít profitot a vállalatnak, és arra a következtetésre jutott, hogyha az újravásárlási szándékra, azaz a lojalitás kezdô lépésére tud hatást gyakorolni, akkor érdemes igazán az elégedettséget elemezni. KANDAMPULLY és SUHARTANTO (2000) egy tanulmányban azt vizsgálta, hogy az elégedettség és a hotel imázsa hogyan hat a fogyasztói lojalitásra a szálloda szektorban. A hotel imázsa és az elégedettség, azon belül is a housekeepinggel kapcsolatos elégedettség, nagymértékben befolyásolják az újravásárlást és az ajánlást, amelyek késôbb, ismétlódő alkalmakkor, lojalitáshoz vezethetnek. A másik fó megállapítása KANDAMPULLY és SUHARTANTO (2000) kutatásának ahhoz köthető, hogy a fogyasztók számára nem egyenló mértékben eredményeznek elégedettséget a különböző szállodai elemek. A tanulmányból kiderült, hogy a személyzetet tartják a legfontosabbnak a vendégek, és csak utána következik sorrendben: az ár, a recepció és az étel-ital kínálat. EKINCI és szerzótársai (2008) létrehoztak egy olyan kiterjesztett modellt, amelyben a szállodai és éttermi szektorban megjelenő, a fogyasztói elégedettségre ható tényezóket, valamint az elégedett- ség következményeit foglalják össze. Véleményük szerint azonban, az elôzetes elvárások helyett az önazonosság, önmegfelelés szegmensét érdemes integrálni a modellbe. Felállítottak és igazoltak két hipotézist arra vonatkozóan, hogy a két minőségi tényező (a fizikai környezet és a személyzet viselkedése) pozitívan befolyásolja a vágyott önazonosságot. GWINNER és szerzótársai (2005) kimutatták, hogy nem elég személyre szabni az ajánlatot, személyre kell szabni a viselkedést is, amit adaptálódásnak hívnak. Azaz, ha a szolgáltatónak sikerül a vevő személyiségét felfedezni, akkor jobban tudnak adaptálódni, ergo elégedettebbé tudják tenni őket. Három személyiségjellemző befolyásolhatja pozitívan a személyközi adaptív viselkedésre való hajlandóságot: a másokkal való érzékenység, az önmegjelenítés és önkinyilatkoztatás módosításának képessége, valamint a vásárlókról szerzett tudás, a vásárlók ismerete. Ahány ember, annyiféle vásárló létezik, így sokszor nem is veszik észre, hogy személyre szabott a szolgáltatás, mert nagyon nehéz a különböző vásárlók mindegyikének megfelelni. A vendéglátás terén (WALL-BERRY 2007) két tényezó befolyásolja a vásárlókat a szolgáltatással kapcsolatos élmény megítélésében. A mechanikus, fizikai környezet elemei és a humán erőforrás, azaz a személyzet. A fizikai környezettel kapcsolatos ítéletüket az előzetes várakozásaik befolyásolják leginkább, ellenben a személyzettel kapcsolatos véleményük kihat a fizikai környezettel kapcsolatosra, azaz ha a vendégnek van egy negatív benyomása a személyzetről, akkor az összélmény nem lesz pozitív akkor sem, ha a fizikai környezet pozitív hatást gyakorolt a vásárlóra. Ha azonban pozitív élményt szerez a vevô a személyzettel történó interakció során, akkor az pozitívan befolyásolja a negatív fizikai környezeti élményhatást.

\subsection{SZEMÉLYISÉGTÍPUSOK HATÁSÁNAK MÉRÉSE A SZÁLLODASZEKTORBAN}

Konkrét kutatási területünkön rendkívül kevés cikk lelhetô fel. Egy szerzőpáros két különböző cikkét érdemes megemlíteni. JANI és HAN (2013) egy dél-koreai város 5 csillagos szállodáit vizsgáló tanulmányban próbálta meg a Big Five Faktor hatásait elemezni a kognitív és az affektív érzékelésre és válaszokra. A tanulmány célja az volt, hogy egy olyan modellt állítson fel, ami a kapcsolatokat az elégedettség, az érzelmek, a kognitív reakciók, a viselkedés és a társadalmi összehasonlítás viszonylatában definiálja. Egy későbbi kutatásában viszont JANI és HAN (2014) többek között azt vizsgálta, hogy a személyiségtípusoknak milyen közvetlen hatása van az elégedettségre. Szemben a korábbi kutatási gyakorlatokkal, igyekeztek mind 
az öt faktor közvetlen hatását vizsgálni. Az öt faktorból négynél (nyitottság, tudatosság, extraverzió, barátságosság) a pozitív hatást vizsgálták, míg az érzelmességnél a negatívat.

\subsection{HIPOTÉZISEK}

MOORADIAN és OLVER (1997) egy tanulmányban az extraverzió esetén pozitív, a neuroticitás esetén negatív hatást talált az autóvásárlók között az elégedettségükre nézvén. FAULLANT és szerzőtársai (2011) a félelem és az öröm között találtak különbséget a fogyasztói összelégedettséget vizsgálva. LIN (2010) a videojátékot vásárlók elégedettségének vizsgálata során azt találta, hogy a barátságosság erősen, míg a nyitottság mérsékelten pozitív hatással van az effektív lojalitásra. LEE és szerzőtársainak (2009) tanulmánya szerint a lojalitás előszobája az elégedettség. ORTH és munkatársai (2010), valamint JANI és HAN (2014) kutatásait alapul véve fogalmaztuk meg hipotéziseinket. Négy esetben pozitív irányú hatást várunk, míg egy esetben negatívat. Mivel HAN és RYU (2009) megállapította, hogy a fizikai környezet külön elemet képez az összelégedettség során, a szakirodalmi felvezetôvel kiegészítve két fő releváns faktort (személyzet és fizikai környezet) állapítottunk meg az elégedettség méréséhez. Az alábbi hipotézisek kerültek megfogalmazásra:

- $\mathrm{H}_{1}$ : A neuroticitás, érzelmesség személyiségtípus faktor szignifikánsan negatív irányban befolyásolja a (a) személyzettel és a (b) fizikai környezettel kapcsolatos elégedettség faktort.

- $\mathrm{H}_{2}$ : Az extraverzió személyiségtípus faktor szignifikánsan pozitív irányban befolyásolja a (a) személyzettel és a (b) fizikai környezettel kapcsolatos elégedettség faktort.

- $\mathrm{H}_{3}$ : A nyitottság személyiségtípus faktor szignifikánsan pozitív irányban befolyásolja a (a) személyzettel és a (b) fizikai környezettel kapcsolatos elégedettség faktort.

- $\mathrm{H}_{4}$ : A barátságosság személyiségtípus faktor szignifikánsan pozitív irányban befolyásolja a (a) személyzettel és a (b) fizikai környezettel kapcsolatos elégedettség faktort.

- $\mathrm{H}_{5}$ : A tudatosság, lelkiismeretesség személyiségtípus faktor szignifikánsan pozitív irányban befolyásolja a (a) személyzettel és a (b) fizikai környezettel kapcsolatos elégedettség faktort.

\subsection{KUTATÁSMÓDSZERTAN}

Kutatásunk jellegéból adódóan kérdőíves online megkérdezést alkalmaztunk. A módszer előnyei, hogy alacsony a társadalmi elvárásoknak megfe- lelő válaszadás, magas a kényes kérdések feltevésének lehetősége, nagyon gyors és alacsonyak a költségei (MALHOTRA-SIMON 2009). Ezek az előnyök jelen esetben azért voltak fontosak, mert kutatásunk személyiségtesztre vonatkozó állításai így kevésbé adnak torz vagy hamis adatokat, hisz anonim módon, online tehettünk fel helyenként kényes kérdéseket (JANI-HAN 2013).

Az elemzés módszeréül a faktoranalízist, majd a korrelációelemzést alkalmazzuk, mint ahogy azt a legtöbb tanulmány teszi, ha a személyiségtényezőket hasonlítja össze valamely másik tényezóvel (LU-HU 2005, KUO-TANG 2013, NAUDE et al. 2016). Maga a Big Five Faktor teszt egyszerú, rövid állításokból áll. Bár általában az egyszerú állítások pszichometrikailag alsóbbrendúek a komplexebb állításokhoz képest, mégis több előnye van. A teszt felépítése az egyszerú, 10 állításos módszertől egészen a több száz állításosig terjedhet. A legismertebb a 240 állításos sor, amelyet COSTA és McCRAE fejlesztett ki 1992-ben. Kitöltése körülbelül 45 percet vesz igénybe. Ennek van egy csökkentett, 60 kérdéses verziója, de GOLDBERG (1992) 100 állításos tesztsora is a legismertebbek között van. Ezeknek a komplex redukciójából alakultak ki a 44, 30, 25, 10 és 5 állításos sorok, elsősorban az interneten futtatható megkérdezéseknek köszönhetően. A rövid tesztek ugyanolyan hatékonyan múködnek az öt faktor mentén, mint hoszszabb társaik, ráadásul 5-10 perc alatt kitölthetők (YOO-GRETZEL 2011). COSTA és McCRAE (1988) longitudinális és keresztmetszeti adatok segítségével kimutatta, hogy a 21 és 96 évesek között némi visszaesés tapasztalható az aktivitás, a nyitottság, a kezdeményezőkészség és a pozitív érzések terén. Emellett azt is igazolták, hogy a válaszadók személyisége 30 éves kor felett stabilizálódik.

Ha a személyiségtesztet korrelálni szeretnénk valamilyen más tényezőhöz, akkor másképpen kell értékelni a kapcsolat erôsségének mértékét. JANI és HAN $(2013,2014)$ mindkét kutatásában erôs kapcsolatként értékelte a 0,3 körüli Pearson-féle korrelációs értéket, miközben ez az általános skálán gyenge közepesnek számítana. Személyiségtesztek esetében nagyon ritka az, hogy 1-hez közelítô Pearson-féle korrelációs értéket kapjon a kutató. Ezen túlmenóen a személyiségtesztek hatásának vizsgálatánál komolynak veszik azokat az eredményeket is, ahol nincsen szignifikáns kapcsolat (RÓZSA et al. 2006).

Fontos megjegyezni, hogy a Big Five Faktor (BFF) teszt csak a személyiségtípusok azonosítására szolgál, és nem arra, hogy útmutatót adjon az alanynak, hogy milyen irányba kellene fejlődnie, változnia. Két - 1982 és 2009 között végzett - longitudinális, amerikai főiskolások körében végzett 
Lektorált tanulmányok

kutatás (TWENGE-FOSTER 2010, TWENGECAMPBELL 2008) igazolta, hogy a fiatalabb korosztályok szignifikánsan egyre nárcisztikusabbnak és önérzetesebbnek mutatkoznak, illetve magasabb önbecsüléssel rendelkeznek. Így egy késő $Y$ vagy Z generációs fiatalnak egy baby-boomerhez képest akár $86 \%$-kal is magasabb lehet az „önérzetesség-értéke", illetve hajlamosabbak a depresszióra és szorongóbbak, mint a korábbi generációk hasonló korú tagjai.

Ezen tényezók figyelembevétele alapján azt a 25 állításos tesztsort használtuk, amelyet YOO és GRETZEL (2011) fejlesztett ki. Javaslatuk szerint öt pontos Likert skálán kell mérni a válaszokat. A teszt öt személyiség faktor mentén öt-öt alapállításból épül fel. Az öt faktor: a neuroticitás vagy érzelmesség, az extraverzió, a nyitottság, a barátságosság és a tudatosság vagy lelkiismeretesség.

A neuroticitás az a típus, amikor az egyén pszichológiai értelemben véve állandóan szorong, és mindenben veszélyt érez. Önmagában véve egy instabil jellemzô. Az ilyen típusú személyek nem magabiztosak, aggódóak, pesszimisták, lehangoltak. Az extraverzió olyan típust jelent, aki sok és intenzív személyközi interakciót próbál megélni, könnyen kerül barátságba másokkal, jellemzô rájuk a barátságosság, a társaságkedvelés, a beszédesség és az ambiciózusság. A nyitottság, az újdonságokat keresgélő, azokban elmerülő proaktív hozzáállást jelenti, jellemző rájuk, hogy ötletesek, kíváncsiak, érdeklődőek, eredetiek és széles látókörúek. A barátságosság arra vonatkozik, hogy az egyén igyekszik másokkal minden téren empatikus lenni, jellemzô rájuk, hogy együttmúködőek, elózékenyek, rugalmasak, jó természetúek és toleránsak. Végül a tudatosság, lelkiismeretesség az egyén teljesítményének hatékony és részletekbe menően körültekintő kiaknázására vonatkozó hajlam, jellemzô rájuk a pontosság, a megbízhatóság, az eltökéltség és az eredménykényszer (YOOGRETZEL 2011, GOLDBERG 1992). A barátságosság tekintetében TURIANO és szerzőtársai (2012) rámutattak, hogy minél inkább jellemez valakit ez a faktor, annál kevésbé érzi magát egészségesnek. Hasonló mondható el a neuroticitás esetén, míg a tudatosság faktoránál éppen fordítva van, azaz minél tudatosabb valaki, annál jobban érzi magát.

JANI és HAN $(2013,2014)$ kérdőíveikben faktorok szerint, egymás után tették fel az öt-öt állítást. A kutatók megjegyezték, hogy ez torz adatokat adhat, mert ha például egymás után jönnek azok a kérdések, hogy „Együtt érzek másokkal”, „Törődöm másokkal” és „Tisztelek másokat", akkor a válaszadó könnyebben ad egymás után ugyanolyan pontszámot, szemben azzal, ha ezek a kérdések a kérdôív különböző pontjain merülnek fel. Éppen ezért mi az utóbbi sorrend mellett döntöttünk. A válaszok beérkezése után meg kellett vizsgálni a Cronbach-féle alfa együtthatót, hogy mennyire megbízhatóak a skálák, és javasolt-e a faktorképzés. MALHOTRA és SIMON (2009) szerint a 0,6-os érték általában már megfelelő, de HAIR és szerzôtársai (1998) azt javasolják, hogy a személyiségtípusú változóknál a 0,7-es értéktól felfelé számítsuk egyre megfelelőbbnek a megbízhatóság értékét.

Kérdőívünk második felét az elégedettséggel kapcsolatos kérdések adták. SIDDIQUI (2011), valamint JANI és HAN (2014) módszertanát vettük alapul. JANI és HAN (2014) összességében mérték az elégedettséget, nem tettek fel specializáló kérdéseket, míg SIDDIQUI (2011) szegmentált hat kategóriában. Kutatásunkban vegyítettük a kétféle módszert, de fóként SIDDIQUI kérdéssorát fejlesztettük tovább. Hat témakörból három megtartásra került (kiszolgálás vagy személyzet, kiszolgálásminőség, elégedettség általánosságban), amelyeket kiegészítettünk a kommunikációra utaló kérdéssel, valamint a fizikai környezet témakörével EKINCI és szerzőtársainak munkája (2008) alapján. A fizikai környezetnél BITNER (1992) Servicescape modelljének kategorizálását vettük alapul, azaz szállodai egységenként (szoba, lobby, étterem, wellnessrészleg) kérdeztünk rá a körülvevő feltételekre, mint levegó, hőmérséklet, zaj, zene, illat, a design elemeknek megfeleltethetó funkcionális elemekre, mint elrendezés, berendezés, felszereltség, és végül a jelekre és szimbólumokra, mint például feliratok, alkotások, dekorációk. Végül a személyzet kérdéskörét is kibővítettük SPINELLI és CANAVOS (2000) tanulmánya alapján oly módon, hogy a vendégek elégedettség-észlelésére szignifikánsan ható személyzeti teljesítmény részekre (gondoskodás, barátságosság, fogékonyság az egyedi igényekre, gyorsaság) kérdeztünk rá a minél részletesebb elemzés érdekében.

Hipotéziseink tesztelése a következő módon zajlott: Pearson-féle korrelációelemzéssel megvizsgáltuk a közvetlen, szignifikáns kapcsolatokat a személyiségtípusoknál létrehozott faktorok és az elégedettségre vonatkozó két faktor között. Az összefüggés-vizsgálat módszeréül a korrelációelemzést találtuk a legmegfelelóbbek, mert a 14 elégedettségre vonatkozó állításnak magas lenne a multikollinearitása, ami ellehetetlenítené a regreszszióelemzést.

\section{Eredmények}

A 159 válaszadóból 6-an válaszoltak nemmel a szúrő kérdésre („,Az elmúlt két évben megszállt-e magyarországi wellness szállodában pihenés céljá- 
ból?"), így ők nem kerültek bele az elemzett mintába, mivel számukra azonnal véget ért a kérdőív. Továbbá 4 válaszadó írt külföldi várost arra a kérdésre, hogy melyik városban helyezkedik el a szálloda, amiben megszállt, ezért ők hiába töltötték ki az egész kérdőívet, nem kerülhettek bele a vizsgált mintába. A megmaradt 149 válaszadót érvényesnek tekintettük, mert átmentek a szúrố kérdésen, továbbá magyarországi városban található a szálloda, amelyben megszálltak.

\subsection{A MINTA ÁLTALÁNOS JELLEMZÖI}

A 149 érvényesen válaszoló demográfiai megoszlása a következő volt: 110 nó és 39 férfi töltötte ki a kérdőívet, ami az érvényesen válaszolók 73,8\%-a és 26,2\%-a. Az átlagos életkor 27,03 volt, aminek a szórása 9,74 év. A legfiatalabb érvényesen válaszoló 15, míg a legidősebb 66 éves volt. A legtöbben, 20-an (13,4\%) 24 évesek, és az érvényesen válaszolók több mint kétharmada (69,1\%) 25 éves vagy annál fiatalabb. Ebból következik, hogyha gráf elemzéssel kizárjuk az extrémen kiugró értékeket (24 válaszadó), akkor a megmaradt 125 érvényesen válaszoló átlagéletkora 23,37 év, 3,04 év szórással.

Alapvetôen egy fiatal, nagyvárosi mintát kaptunk elemzésül, akik két-három éjszakát töltöttek el az adott, általában 4 *os vagy 4 *Superior szálláshelyen, ahová leginkább egy-két fóvel utaztak együtt. Arra a kérdésre, hogy egy évben átlagosan hányszor utaznak el hasonló kategóriájú wellness-szállodába, a legtöbben, 63-an, azt válaszolták, hogy egyszer, 39-en azt, hogy kétszer. A többi adattal kiegészülve 1,66 az átlag, 1,06-os szórás mellett. A három kiugró érték kiszúrése itt is inkább a szórásra van hatással, az átlagon féltizednyit csökkent, ami nem számottevő.

\subsection{MEGBÍZHATÓSÁG TESZTELÉSE}

E részfejezetben a 25 személyiségtípusra és a 14 elégedettségre vonatkozó kérdés tesztelését mutatjuk be. A belső konzisztencián alapuló megbízhatóság tesztelésére a Cronbach-féle alfa együtthatót alkalmazzuk (MALHOTRA-SIMON 2009). A mutató segítségével egy több tétel összegzésével megkapott skála megbízhatóságát értékelhetjük. Először a 25 személyiségtípusra vonatkozó állításokat vizsgáljuk meg faktoronként, a neuroticitás faktorával kezdve. Ebben az esetben a Cronbach-féle alfa értéke 0,834, ami megfelel az elméleti háttérben leírt feltételeknek. Az extraverzióval kapcsolatos faktor esetében a Cronbach-féle alfa értéke 0,808, ami szintén eleget tesz az elméleti háttérben taglalt feltételeknek. A nyitottság esetében a Cronbachféle alfa értéke 0,730 . Ez az érték is nagyobb, mint
0,7. A barátságosság személyiségtípus faktora esetében a Cronbach-féle alfa értéke 0,702. Végezetül a tudatosság faktorának Cronbach-féle alfa értéke 0,634, ami már nem optimális a személyiségtípussal foglalkozó kutatások esetén. A személyzettel kapcsolatos hét kérdésre vonatkozóan a Cronbach alfa értéke 0,907, míg a fizikai környezet esetén mért hét változó megbízhatósági szintje 0,848.

\subsection{SZEMÉLYISÉGTÍPUS FAKTOROK LÉTREHOZÁSA}

A személyiségtípusokra vonatkozó 25 kérdés esetében mindenképpen öt faktort kell létrehozni. A személyiségtípusok faktorizálása során először sajátérték alapján kívántuk létrehozni az öt faktort. Ekkor a KMO mutató 0,736-os értéket mutat, ami megfelelő illeszkedést jelent. A Bartlett teszt alapján elvethetô a $\mathrm{H}_{0}$ hipotézis, azaz a megfigyelt változók korrelációs mátrixa nem egységmátrix. A kommunalitások mind a minimum 0,25 feletti értéket veszik fel (legalacsonyabb érték a 0,456). Ekkor 67,7\%-os összvariancia magyarázat mellett 8 faktor jön létre. Ha a magyarázott varianciahányadon alapuló meghatározást vesszük figyelembe és a $60 \%$-os standard minimum értéket vesszük alapul, akkor 7 faktort lehetne létrehozni. Mindkét esetben csak a neuroticitás és az extraverzió személyiségtípus faktor jön létre, pontosan az 5-5 hozzájuk tartozó állítással.

Azokban a tanulmányokban, amelyekben szintén használták a BFF elméletét, a priori megoldást választották a faktorok létrehozásához. Ennél a megoldásnál megadják a programnak (IBM SPSS), hogy öt faktort hozzon létre. Jelen kutatásra adaptálva ezt a megoldást, a KMO mutató ebben az esetben is 0,736-os értéket mutat, ami megfelelő illeszkedést jelent. A Bartlett teszt alapján elvethető a $\mathrm{H}_{0}$ hipotézis, azaz a megfigyelt változók korrelációs mátrixa nem egységmátrix. A kommunalitások mind a minimum 0,25 feletti értéket veszik fel (legalacsonyabb érték a 0,380). Az összvarianciának az 54,36\%-át magyarázzák a létrehozott faktorok. A rotált megoldásban a létrejött faktorsúlyok mindegyike eléri a minimum 0,4-et, a legalacsonyabb faktorsúly értéke 0,507, a legmagasabbé 0,817 (1. táblázat). Ebben az esetben mind az öt faktorba tartozó 5-5 állítás megfeleltethetô a BFF elméletének. A faktorokat az eredeti elméletnek megfelelően neveztük el (neuroticitás vagy érzelmesség, extraverzió, nyitottság, barátságosság, tudatosság vagy lelkiismeretesség). A legerősebb faktorsúlyok a neuroticitás faktorához tartoznak, majd az extraverzió faktora következik, utána jutunk a nyitottság faktorához, majd a barátságosság faktorához, végül pedig a tudatosság faktorához. 
Lektorált tanulmányok

\section{Képzett faktorok}

\begin{tabular}{|c|c|}
\hline Faktor neve & Faktorsúly \\
\hline \multicolumn{2}{|l|}{ Neuroticitás (Cronbach $\alpha=0,834$ ) } \\
\hline Aggódom dolgok miatt & 0,817 \\
\hline Tele vagyok kétségekkel dolgokat illetôen & 0,779 \\
\hline Könnyen kiborulok & 0,745 \\
\hline Könnyen pánikolok & 0,739 \\
\hline A legrosszabbtól tartok & 0,729 \\
\hline \multicolumn{2}{|l|}{ Extraverzió (Cronbach $\alpha=0,808)$} \\
\hline $\begin{array}{l}\text { Sokat beszélgetek különbözó emberekkel az } \\
\text { összejöveteleken }\end{array}$ & 0,812 \\
\hline Könnyen szerzek barátokat & 0,781 \\
\hline Jól érzem magam emberek között & 0,704 \\
\hline Kezdeményezem a beszélgetéseket & 0,669 \\
\hline $\begin{array}{l}\text { Nem bánom, ha a figyelem középpontjában } \\
\text { vagyok }\end{array}$ & 0,559 \\
\hline \multicolumn{2}{|l|}{ Nyitottság (Cronbach $\alpha=0,730$ ) } \\
\hline Az új ötletek izgatottá tesznek & 0,699 \\
\hline Élvezem a dolgok mélyebb értelmét megtalálni & 0,680 \\
\hline Szeretek dolgokról gondolkodni & 0,675 \\
\hline Élvezem, ha új elképzelésekről hallok & 0,650 \\
\hline Élénk képzelôerôvel rendelkezem & 0,507 \\
\hline \multicolumn{2}{|l|}{ Barátságosság (Cronbach $\alpha=0,702)$} \\
\hline Hiszem, hogy mások jószándékúak & 0,757 \\
\hline Bízom abban, amit az emberek mondanak & 0,673 \\
\hline Törődöm másokkal & 0,616 \\
\hline Tisztelek másokat & 0,595 \\
\hline Együtt érzek mások érzéseivel & 0,540 \\
\hline \multicolumn{2}{|l|}{ Tudatosság (Cronbach $\alpha=0,634$ ) } \\
\hline Figyelek a részletekre & 0,648 \\
\hline Mindig felkészült vagyok & 0,612 \\
\hline Igényes vagyok a munkámban & 0,610 \\
\hline Terveket készítek, amelyekhez ragaszkodom & 0,595 \\
\hline A terveimet megvalósítom & 0,554 \\
\hline \multicolumn{2}{|l|}{ Személyzet (Cronbach $\alpha=0,907$ ) } \\
\hline Személyzettel összességében & 0,907 \\
\hline Személyzet gondoskodásával & 0,847 \\
\hline $\begin{array}{l}\text { Személyzet barátságosságával, } \\
\text { közvetlenségével }\end{array}$ & 0,844 \\
\hline Személyzet gyorsaságával, hatékonyságával & 0,806 \\
\hline Szállodai kiszolgálás minőségével & 0,788 \\
\hline $\begin{array}{l}\text { Személyzet fogékonyságával az egyedi } \\
\text { igényeimre }\end{array}$ & 0,748 \\
\hline Szálloda kommunikációjával & 0,694 \\
\hline \multicolumn{2}{|l|}{ Fizikai környezet (Cronbach $\alpha=0,848)$} \\
\hline Lobby berendezésével, felszereltségével & 0,856 \\
\hline Összességében a szálloda belsố környezetével & 0,786 \\
\hline Szálloda hangulatával & 0,776 \\
\hline Szállodai feliratok, jelölések színvonalával & 0,717 \\
\hline Étterem berendezésével, felszereltségével & 0,687 \\
\hline Szobák berendezésével, felszereltségével & 0,644 \\
\hline $\begin{array}{l}\text { Wellnessrészleg berendezésével, } \\
\text { felszereltségével }\end{array}$ & 0,626 \\
\hline
\end{tabular}

Forrás: saját számítás
1. táblázat Ennek az lehet az oka, hogy a faktoronként mért megbízhatósági szintek is ebben a sorrendben csökkennek.

A személyzet faktora esetén a KMO értéke 0,908. A Bartlett teszt alapján elvethetô a $\mathrm{H}_{0}$ hipotézis, a legkisebb kommunalitás 0,392, a legkisebb faktorsúly 0,694 és a magyarázott összvariancia hányad 65,23\%. A fizikai környezettel kapcsolatos faktor esetén a KMO értéke 0,881, a Bartlett teszt alapján elvethetô a $\mathrm{H}_{0}$ hipotézis, a legkisebb kommunalitás 0,482, a legkisebb faktorsúly 0,626 és a magyarázott összvariancia hányad 53,50\%.

\subsection{HIPOTÉZISEK TESZTELÉSE}

Összesen tíz lehetséges korrelációs eset van (az öt személyiség faktor és a két elégedettség faktor szorzata). 5\%-os szignifikancia szint mellett egy, míg 10\%-os szignifikancia szintnél két esetben van kapcsolat (2. táblázat). Az extraverzióra $\left(\mathrm{H}_{2}\right)$, a nyitottságra $\left(\mathrm{H}_{3}\right)$ és a neuroticitásra $\left(\mathrm{H}_{1}\right)$ vonatkozó hipotéziseket elvethetjük, mert egyik esetben

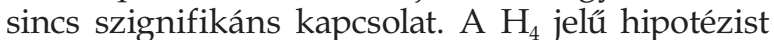
$10 \%$-on, a $\mathrm{H}_{5}$ jelút pedig $1 \%$-os szignifikancia szint mellett tudjuk elfogadni.

\section{2. táblázat}

\section{Korrelációk a látens változók között}

\begin{tabular}{|l|c|c|}
\hline & Személyzet & Fizikai környezet \\
\hline Neuroticitás & 0,106 & 0,048 \\
\hline Extraverzió & $-0,004$ & 0,008 \\
\hline Nyitottság & $-0,044$ & $-0,081$ \\
\hline Barátságosság & 0,002 & $0,137^{*}$ \\
\hline Tudatosság & $0,225^{* * *}$ & 0,083 \\
\hline \multicolumn{3}{|c|}{} \\
& ${ }^{*} p<0,1$ \\
& \\
\hline
\end{tabular}

Forrás: saját számítás

A két különböző elégedettség faktorra összesen két esetben két személyiségtípus hat szignifikánsan, bár a barátságosság faktorának p-értéke elég magas, 0,097 és csak 10\%-on szignifikáns. Az irányok a szignifikáns kapcsolatok esetén megfelelnek a szakirodalom alapján elvártaknak.

\section{4. Összegzés, következések és gyakorlati javaslatok}

Kutatásunkban a Big Five Faktor személyiségteszt alapján 25 állításból kialakítottuk az öt személyiségtípus faktort, melyek hatását a Pearson-féle korrelációelemzéssel vizsgáltuk. Az öt személyiségtípusra vonatkozó öt hipotézis $\left(\mathrm{H}_{1}, \mathrm{H}_{2}, \mathrm{H}_{3}, \mathrm{H}_{4}, \mathrm{H}_{5}\right)$ közül hármat, a $\mathrm{H}_{1}$ neuroticitásra, a $\mathrm{H}_{2}$ extraverzi- 
óra és a $\mathrm{H}_{3}$ nyitottságra vonatkozókat elvetettük, mert a két elégedettséggel kapcsolatos faktor közül egyikre sem volt szignifikáns hatásuk. Ebból azt a következtetést vonhatjuk le, hogy a neuroticitás esetében elképzelhető, hogy az erre a személyiségtípusra jellemzó jegyek helyett, válaszadóink esetében más jellemzó dominált, például az aggódás. Akikre a nyitottság a jellemző, azok egyediek, szeretik az új dolgokat, eredetiek és széleslátókörúek, így lehet, hogy ők kritikusabbak, és ezért diverzifikáltabbak a válaszok, így nem született koherens eredmény. $\mathrm{A} \mathrm{H}_{5}(\mathrm{~b})$ hipotézist teljesen, a $\mathrm{H}_{4}$ (a) jelút részben fogadtuk el. $\mathrm{A} \mathrm{H}_{4}(\mathrm{~b})$ esetében a barátságosság személyiségtípus pozitív irányban hat a fizikai környezettel kapcsolatos faktorra, de a p-érték 0,097, ami csak 10\%-os szignifikancia szinten fogadható el. $\mathrm{A} \mathrm{H}_{5}$ (a) hipotézis esetében a tudatosság személyiségtípus pozitív irányban befolyásolja a személyzettel kapcsolatos elégedettség faktort.

A nemeket tekintve a mintánkban magas a nók aránya, de szignifikáns különbség a nemeket illetően sincs, sem az elégedettség faktorok (bár a nók kicsit elégedettebbek voltak a férfiaknál mindkét esetben), sem a személyiségtípus faktorok esetén. A lakhely és az iskolai végzettség tekintetében sincs szignifikáns különbség az elégedettség tényezőkkel kapcsolatosan.

Annak, hogy a legtöbb esetben a tudatosság személyiségtípus faktor volt a szignifikánsan befolyásoló tényező, az lehet az oka, hogy ebbe a faktorba tartoznak a legracionálisabb személyiségjegy állítások, amelyek az értékelések során logikusságot feltételeznek. Ennek ellentmond, hogy az ebbe a faktorba tartozó állításoknak a legalacsonyabb a megbízhatósági szintje. Emellett az is befolyásolhatta a tudatosság és a barátságosság szignifikáns hatását, hogy csak ez a két faktor korrelál pozitívan a korral, tehát minél idősebb volt egy válaszadó, annál inkább jellemzó volt rá ez a faktor. A tudatosság esetén érdemes megemlíteni, hogy ennél a személyiségtípusnál a legmagasabb a percepciók szelektálásának hányada. A hétköznapi körülményekhez jól alkalmazkodó személyben az érdeklődésre számot tartó alapvetô érzelem vagy az érdeklődési séma folyamatos a tudatban, ami az új információ feldolgozásához vagy egy új és eltérô érzelmet kiváltó emlékezethez vezet (IZARD 2007). A barátságosság tekintetében a fizikai környezettel kapcsolatos pozitív hatást az is befolyásolhatta, hogy ez a személyiségjegy szignifikánsan pozitívan korrelál a „Hány fơvel utazott?” kérdéssel (Pearson-féle érték 0,199; p<0,05). Valószínúleg ekkor, ha több fővel utaznak, fontosabb a belső tér kialakítása.

A válaszadóink koruk előrehaladtával egyre magasabb kategóriájú szállodában szálltak meg.
Az megállapítható, hogy a személyzettel kapcsolatos elégedettséget befolyásolja leginkább a személyiség, azon belül is a tudatosság. Mindez azt jelenti, hogy szemben a személyzettel kapcsolatos elégedettséggel, a fizikai környezettel kapcsolatos élményt alapvetóen nem a személyiség határozza meg. A személyzettel kapcsolatos élmény megítélésében vannak különbségek a személyiségtípusok között, mivel bizonyos személyiségtípus esetén van szignifikáns kapcsolat, más esetben viszont nincs. A szállodai szolgáltatásnyújtás jelentôs számú tárgyiasult és nem tárgyiasult összetevőt tartalmaz, illetve igényel. A vendéglátó a látható elemeken túlmenően biztonságot, pszichológiai és fizikai komfortot is kínál (ARIFFIN et al. 2011). Emellett a fizikai környezet "teljesítménye” kézzelfogható és tapintható, könnyebben értékelhetô objektív módon, mint a személyzettel kapcsolatos élmény megítélése. Sokkal könnyebb a sztenderdeket a fizikai környezet létrehozása során kialakítani, ezért is igyekeznek a magasabb minőség érdekében erre törekedni a szállodaláncok (KARAKASNÉ MORVAY 2014).

\subsection{MENEDZSERI JAVASLATOK}

Elsősorban a két fő szolgáltatási területet, a személyzet, illetve a fizikai környezet elemeivel kapcsolatos elégedettséget mértük, mert a korábbi, szolgáltatások során felmerülő elégedettséggel foglalkozó tanulmányok is ezekben az esetekben mutattak ki szignifikáns hatást. Ebból azt gondoljuk, hogy mindkét területet hozzá kell igazítani a vendégek ízléséhez. Természetesen nem lehet minden vendégnek megfelelni, azonban a fizikai környezet esetében érdemes olyan tereket, részegységeket kialakítani, amelyek a különböző személyiségú vendégek különböző igényeit elégítik ki (hangulatos zene az egyes lounge-okban, eltérő tematikájú vagy berendezésú szobák, éttermek létrehozása). Érdemes lenne a személyzet hozzáállását, kommunikációját fejleszteni oly módon, hogy néhány keresztkérdéssel kicsit jobban megismerje a vendéget, akár annak kevésbé tudatos igényeit is. Emellett a személyzetnek olyan hozzáállást kellene tanúsítania a fizikai környezet átalakítása során kialakított különböző területeken, ami az adott rész igényeit kielégíti. Érdekes lenne egy olyan szállodát létrehozni, amelynek több szárnya van, melyeket az öt személyiségtípus igényei mentén rendeznek be, majd ezután mérik a különbségeket.

Összességében azt javasoljuk, hogy érdemes egy olyan vezetőséget kinevezni, akik megértőek a dolgozók igényeivel, ugyanakkor képesek egy gondoskodó, fogékony, hatékony és a vendégeket támogató személyzetet összeállítani. Emellett fontos 
a fizikai terek hasznos és igényes kialakítása, melyeket olyan egymástól különböző területi egységek (bár, lounge, lobby, sport, interaktív egységek) egészítenek ki, amelyekbe az azonos érdeklődésú vagy a hasonló személyiség vonásokkal bíró vendégek térnek be (social servicescape).

\subsection{A KUTATÁS KORLÁTAI ÉS FEJLESZTÉSI LEHETŐSÉGEI}

Kutatásunk egyik korlátja, hogy eredményeink nem tekinthetők reprezentatívnak sem a kor, sem a nemek tekintetében. Mindettől függetlenül, mivel alapvetően hatások vizsgálatát túztük ki célul, kutatási eredményeink jó alapot adhatnak további vizsgálatokhoz. A személyiségtípus faktorok megbízhatósági szintje egy esetben nem éri el az elvárt 0,7-es értéket, ami szintén további kutatásokat igényel. Eredményeinket javította volna egy nagyobb mintán végzett elemzés vagy a Big Five Faktor tesztnek nem a 25 állításos, hanem a 60, a 100, esetleg a 240 állításból álló változatának megkérdezése. Emellett a mintában viszonylag jelentós arányt képeznek a fiatalok, illetve a nemek eloszlása erósen a nők felé tolódik. A jövóben érdemes lenne tovább vizsgálni, hogy az elégedettségnek van-e hatása a lojalitásra, ezáltal - közvetett módon - a profitabilitásra, köszönhetóen a kiszámítható újravásárlásnak. A későbbiekben mélyinterjú elemzéssel lehetne kutatni a különbözó személyiségtípusú emberek igényeit, illetve azt, hogy mely szolgáltatás-tényezốt miért tartja fontosnak, és hogy mely elem befolyásolja. Ezzel a módszerrel az elégedettséget befolyásoló tényezők mélységét lehetne megismerni, majd tovább elemezni. Érdemes lenne mérni a személyiségtípus, mint moderáló tényezó hatását a modellben, további befolyásoló tényezők azonosítása mellett.

\section{Köszönetnyilvánítás}

Jelen publikáció az Európai Unió (Európai Szociális Alap) és Magyarország társfinanszírozása által biztosított forrásból az EFOP3.6.3-VEKOP-16-2017-00007 azonosítószámú „Tehetségból fiatal kutató - A kutatói életpályát támogató tevékenységek a felsőoktatásban" címú projekt keretében jött létre.

\section{Felhasznált irodalom}

ARIFFIN, A. A. M. - MAGHZI, A. - AZIZ, N. A. (2011): Understanding hotel hospitality and differences between local and foreign guests. International Review of Business Research Papers. 7(1). pp. 340-349.
BAKER, J. (1987): The role of the environment in marketing services: The consumer perspective. In: Czeipel, J. - Congram, C. - Shanahan, J. (eds): The services challenge: Integrating for competitive advantage. American Marketing Association Proceedings Series. Amer Marketing Assn, Chicago. pp. 79-84.

BAUER A. - BERÁCS J. - KENESEI ZS. (2009): Marketing alapismeretek, Aula Kiadó, Budapest.

BITNER, M. J. (1992): Servicescapes: The Impact of Physical Surroundings on Customers and Employees. Journal of Marketing. 56(2). pp. 5771.

COSTA, P. T. - McCRAE, R. R. (1988): Personality in adulthood: A six-year longitudinal study of self-reports and spouse ratings on the NEO Personality Inventory. Journal of Personality and Social Psychology. 54(5). pp. 853-863.

COSTA, P. T. - McCRAE, R. R. (1992): NEO PI-R professional manual. Psychological Assessment Resources.

EKINCI, Y. - DAWES, P. L. - MASSEY, G. R. (2008): An extended model of the antecedents and consequences of consumer satisfaction for hospitality services. European Journal of Marketing. 42(1/2). pp. 35-68.

FAULLANT, R. - MATZLER, K. - MOORADIAN, T. A. (2011): Personality, basic emotions, and satisfaction: primary emotions in the mountaineering experience. Tourism Management. 32(6). pp. 1423-1430.

GOLDBERG, L. R. (1992): The development of markers for the Big-Five factor structure. Psychological Assessment. 4(1). pp. 26-42.

GWINNER, K. P. - BITNER, M. J. - BROWN, S. W. (2005): Through Employee Adaptiveness. Journal of Service Research. 8(2). pp. 131-148.

HAIR, J. F. - ANDERSON, R. E. - TATHAM, R. L. - BLACK, W. (1998): Multivariate data analysis. (5th edition). Prentice Hall, Upper Saddle River.

HAN, H. - RYU, K. (2009): The roles of the physical environment, price perception, and customer satisfaction in determining customer loyalty in the restaurant industry. Journal of Hospitality and Tourism Research. 33(4). pp. 487-510.

IZARD, C. E. (2007): Basic Emotions, Natural Kinds, Emotion Schemas, and a New Paradigm. Perspectives on Psychological Science. 2(3). pp. 260-280.

JANI, D. - HAN, H. (2013): Personality, social comparison, consumption emotions, satisfaction, and behavioral intentions. International Journal of Contemporary Hospitality Management. 25(7). pp. 970-993. 
JANI, D. - HAN, H. (2014): Personality, satisfaction, image, ambience, and loyalty: Testing their relationships in the hotel industry. International Journal of Hospitality Management. 37. pp. 11-20.

KANDAMPULLY, J. - SUHARTANTO, D. (2000): Customer loyalty in the hotel industry: the role of customer satisfaction and image. International Journal of Contemporary Hospitality Management. 12(6). pp. 346-351.

KARAKASNÉ MORVAY K. (2014): A minőségfejlesztés és a vendégelégedettség összefüggései a hazai wellness szállodákban. Doktori (PhD) értekezés. Szent István Egyetem, Gazdálkodás és Szervezéstudományok Doktori Iskola, Gödöllő.

KENESEI ZS. - KOLOS K. (2014): Szolgáltatásmarketing és -menedzsment. Alinea Kiadó, Budapest.

KUO, T. - TANG, H. L. (2013): Personality's Influence on Facebook's Privacy Settings: A Case of College Students in Taiwan. In: Marinos, L. - Askoxylakis, I. (eds): Human Aspects of Information Security, Privacy, and Trust. HAS 2013. Lecture Notes in Computer Science, vol 8030. Springer, Berlin, Heidelberg. pp. 127-134.

LEE, Y. K. - BACK, K. J. - KIM, J. Y. (2009): Family restaurant brand personality and its impact on customer's emotion, satisfaction, and brand loyalty. Journal of Hospitality and Tourism Research. 33(3). pp. 305-328.

LIN, Y. I. (2010): The interactive effect of Gestalt situations and arousal seeking tendency on customers' emotional responses: matching color and music to specific servicescapes. Journal of Services Marketing. 24(4). pp. 294-304.

LU, L. - HU, C-H. (2005): Personality, leisure experiences and happiness. Journal of Happiness Studies. 6. pp. 325-342.

MALHOTRA, N. K. - SIMON, J. (2009): Marketingkutatás. Akadémia Kiadó, Budapest.

MILFELNER, B. - KORDA, A. P. (2011): Hotel image and guests satisfaction as a source of sustainable competitive advantage. International Journal Sustainable Economy. 3(1). pp. 92-106.

MOORADIAN, T. A. - OLVER, J. M. (1997): I cant' get no satisfaction: the impact of personality and emotion on postpurchase processes. Psychology \& Marketing. 14(4). pp. 379-393.

NAUDE, R. - KRUGER, S. - DE BEER, L. T. SAAYMAN, M. - JONKER, J. (2016): The relationship between personality types and leisure time activities amongst Casino employees' workplace expectations. SA Journal of Human Resource Management. 14(1). pp. 1-11.

$\mathrm{OH}, \quad$ H. (1999): Service quality, customer satisfaction, and customer value: A holistic perspective. International Journal of Hospitality Management. 18(1). pp. 67-82.

ORTH, U. R. - LIMON, Y. - ROSE, G. (2010): Storeevoked affect, personalities, and consumer emotional attachment to brands. Journal of Business Research. 63(11). pp. 1202-1208.

RÓZSA S. - NAGYBÁNYAI NAGY O. - OLÁH A. (2006): A pszichológiai mérés alapjai. Bölcsész Konzorcium, Budapest.

SIDDIQUI, K. (2011): Personality influences on customer satisfaction. African Journal of Business Management. 6(11). pp. 4134-4141.

SPINELLI, M. A. - CANAVOS, G. C. (2000): Investigating the relationship between employee satisfaction and guest satisfaction. The Cornell Hotel and Restaurant Administration Quarterly. 41(6). pp. 29-33.

TURIANO, N. A. - WHITEMAN, S. D. HAMPSON, S. E. - ROBERTS, B. W. MROCZEK, D. K. (2012): Personality and substance use in midlife: Conscientiousness as a moderator and the effects of trait change. Journal of Research in Personality. 46(3). pp. 295305.

TWENGE, J. M. - CAMPBELL, S. M. (2008): Generational differences in psychological traits and their impact on the workplace. Journal of Managerial Psychology. 23(8). pp. 862-877.

TWENGE, J. M. - FOSTER, J. D. (2010): Birth Cohort Increases in Narcissistic Personality Traits Among American College Students, 1982-2009. Social Psychological and Personality Science. 1(1). pp. 99-106.

WALL, E. A. - BERRY, L. L. (2007): The Combined Effects of the Physical Environment and Employee Behavior on Customer Perception of Restaurant Service Quality. Cornell Hotel and Restaurant Administration Quarterly. 48(1). pp. 59-69.

YOO, K. H. - GRETZEL, U. (2011): Influence of personality on travel-related consumergenerated media creation. Computers in Human Behavior. 27(2). pp. 609-621.

ZEITHAML, V. A. - BERRY, L. L. PARASURAMAN, A. (1993): The nature and determinants of customer expectations of service. Journal of the Academy of Marketing Science. 21(1). pp. 1-12. 